\title{
Revus
}

Journal for Constitutional Theory and Philosophy of Law / Revija za ustavno teorijo in filozofijo prava

in print $\mid 2019$

(- Already online -)

\section{A challenge to Bix's interpretation of Kelsen and Hart's views on the normativity of law}

\section{Torben Spaak}

\section{OpenEdition \\ Journals}

Electronic version

URL: http://journals.openedition.org/revus/4561

DOI: 10.4000/revus.4561

ISSN: $1855-7112$

\section{Publisher}

Klub Revus

Brought to you by Stockholm University Library

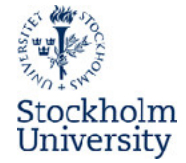

\section{Electronic reference}

Torben Spaak, " A challenge to Bix's interpretation of Kelsen and Hart's views on the normativity of law », Revus [Online], in print | 2019, Online since 06 October 2018, connection on 19 January 2019. URL : http://journals.openedition.org/revus/4561; DOI : 10.4000/revus.4561

This text was automatically generated on 19 January 2019 .

All rights reserved 


\title{
A challenge to Bix's interpretation of Kelsen and Hart's views on the normativity of law
}

\author{
Torben Spaak
}

1 Brian Bix discusses questions of legal normativity, arguing (1) that Hans Kelsen's theory of the basic norm is best understood as saying that a person may choose to presuppose the basic norm in order to interpret the actions of legal officials normatively; (2) that $\mathrm{H}$. L. A. Hart is best understood as espousing a sui generis view of legal normativity; and (3) that Hart's view is preferable to the rather popular view that law makes some sort of moral claim. I accept (1) but think it is rather trivial. I find (2) plausible but the view itself problematic, and I am therefore skeptical of (3). I will discuss the claims in that order, concentrating on what Bix has to say about Kelsen.

2 Bix considers the so-called transcendental argument in support of the view that one needs to presuppose the basic norm in order to account for the normativity of law (Bix 2018: 32). The argument is that some thing, $X$, must exist if $X$ is necessary to account for the existence of something else, $Y$, which does exist. Accordingly, since (we assume) law exists and is normative ( $Y$ ), and since the presupposition of the basic norm is necessary to account for the normativity of law $(X)$, the presupposition of the basic norm is necessary ( $X)$. Following Stanley Paulson, however, Bix objects that Kelsen has not shown that there is no other explanation for the normativity of law besides the presupposition of the basic norm, and that therefore the transcendental arguments fails. Bix proposes instead a less ambitious way of accounting for the normativity of law along Kelsenian lines, which has it that since one cannot deduce an 'ought' from an 'is', one has to justify any legal norm by reference to a higher legal norm, and since this will take one to the historically first constitution, one needs to presuppose the basic norm in order to establish the normativity (or validity) of that constitution.

3 Bix notes in conclusion (Bix 2018: 33) that the suggested interpretation of the theory of the basic norm has been objected against on the grounds that it portrays the theory as being much less important than Kelsen appears to have thought it was, and that this 
suggests the interpretation is mistaken. He does not, however, agree that his interpretation makes the theory unimportant. To the contrary, he says (Bix 2018: 33), the theory

offers important insights about the logic of norms, about what follows from the fact that someone reads the actions of officials normatively, and it offers related insights regarding the connections (or lack thereof) between law and morality, and regarding whether (or not) one has an obligation to accept or presuppose the basic norm of one's legal system.

4 Although I agree with much of what Bix says about Kelsen, I shall raise four objections. First, Bix does not say anything about the strength, or stringency, of normativity in Kelsen's theory (on different grades of normativity, see Copp 2007: ch. 8). Like the Scandinavian realists, but unlike H. L. A. Hart, Kelsen (1992: 23) assumes that law is (supposed to be) normative in a rather strong sense. As he sees it, the legal 'ought' is a relative a priori category with the help of which we can comprehend the legal data by normatively connecting legal consequences with legal conditions: “'ought' expresses the unique sense in which the material facts belonging to the system of the law are posited in their reciprocal relation." He aims to clarify the sense of 'ought' he has in mind by introducing a distinction between a subjective and an objective 'ought,' explaining that whereas any act of will directed at the behavior of another person expresses a subjective 'ought,' only certain acts of will express an objective 'ought' and can properly be called norms. As he sees it (Kelsen 1960: 7), an action, $\varphi$, is such that an agent, $A$, objectively ought to perform $\varphi$ if, and only if, A ought to perform $\varphi$ not only from the point of view of the norm giver, $B$, but also from the point of view of a disinterested third party, $C$. That is to say, Kelsen thinks of the normativity of law as being independent of the particular perspective adopted by one or more individuals.

5 Joseph Raz has introduced a distinction between justified and social normativity, which further illuminates Kelsen's view of normativity, arguing that whereas Hart operates with a conception of social normativity, Kelsen operates with a conception of justified normativity. Raz (2009: 134) argues:

Two conceptions of the normativity of law are current. I will call them justified and social normativity. According to the one view legal standards of behaviour are norms only if and in so far as they are justified. They may be justified by some objective and universally valid reasons. They may be intuitively perceived as binding or they may be accepted as justified by personal commitment. On the other view standards of behaviour can be considered as norms regardless of their merits. They are social norms in so far as they are socially upheld as binding standards and in so far as the society involved exerts pressure on people to whom the standards apply to conform to them. Natural law theorists characteristically endorse the first view, positivists usually maintain the second view.

Raz does not really explain what justified normativity is in this quotation, but I take it that he means, roughly, that a standard is normative in the relevant sense if, and only if, it provides the subjects with categorical reasons for action, in the sense that they apply to and bind the agent independently of his or her desires, wishes, or goals. ${ }^{1}$

7 I believe Raz is right to attribute to Kelsen the view that legal norms are normative in the sense of justified normativity, since if Kelsen had thought of legal normativity along the lines of social normativity, he would not have needed to introduce the theory of the basic norm. One may, however, wonder why Kelsen believed that the normativity of law needs to be so strong, given that he himself appears to have been either a non-cognitivist or else a meta-ethical relativist who does not believe that there is, or can be, such a thing as 
justified normativity (see, e.g., Kelsen 1999 [1945]: 6-8; Kelsen 1960: 65-68). What, exactly, could the point be of introducing the theory of the basic norm to account for the normativity of law within the framework of legal positivism, if one also espouses a metaethical view according to which the relevant type of normativity does not and cannot exist? Instead, Kelsen might have chosen the path of Scandinavian realist Karl Olivecrona (1939 and 1971), who, having also argued that there is no such thing as justified normativity (Olivecrona called it 'binding force'), put forward an account of legal norms (rules) as (what he called) independent imperatives, which could not (cannot) establish legal relations, but which could (can) cause human behavior. Of course, Olivecrona's theory of legal rules is itself problematic.

8 Second, Kelsen proposes the transcendental argument fully aware that it proceeds within the framework of legal positivism, pointing out that legal positivism is the only scientifically acceptable theory of law. As I have argued elsewhere (Spaak 2018), he reasons that since one cannot deduce an 'ought' from an 'is' (Hume's law), and since there is no conceptual connection between law and morality (the separation thesis of legal positivism), a person who wishes to conceive of the legal raw-materials as a system of valid (binding) norms needs to presuppose the basic norm. In Kelsen's (1999: 116) words:

The ultimate hypothesis of positivism is the norm authorizing the historically first legislator. The whole function of this basic norm is to confer law-creating power on the act of the first legislator and on all the other acts based on the first act. To interpret these acts of human beings as legal acts and their products as binding norms, and that means to interpret the empirical material which presents itself as law as such, is possible only on the condition that the basic norm is presupposed as a valid norm. The basic norm is only the necessary presupposition of any positivistic interpretation of the legal material.

9 I believe this is worth pointing out because it is clear that the transcendental argument cannot succeed in Kelsen's case unless one rules out from the very beginning the possibility that the normativity (validity) of law may be grounded in morality, and of this Kelsen is well aware. But even if one does make this assumption, it is not certain that the argument will succeed. For example, the very starting point of the argument - that law is necessarily normative - might be mistaken. As we shall see, Kelsen is explicit that one may, but need not, presuppose the basic norm. This suggests that he is aware that not everyone accepts the premises of the argument, and that those who don't cannot be (intellectually) forced to do so.

10 Third, if I understand him correctly, Bix believes the theory of the basic norm offers important insights into the relation (or lack thereof) between law and morality. However, even if the theory of the basic norm implies that "every normative system is selfcontained and independent of every other normative system" as Bix holds (Bix 2018: 28), nothing about the presence or absence of a necessary connection between law and morality follows from this. For even if law is independent of any other normative system, law may nevertheless be necessarily moral by virtue of some of its necessary properties. As I see it, the theory of the basic norm is a legal positivist's response to the problem of the normativity of law. Kelsen starts from the assumption that there is no necessary connection between law and morality and offers the theory of the basic norm as an explanation of how legal positivists can nevertheless view law as being normative - as I have said, if he had not accepted the separation thesis, he would not have needed to introduce the theory of the basic norm. 
11 Fourth, and this is my main concern, the interpretation of Kelsen's theory of the basic norm that Bix proposes is not very novel. ${ }^{2}$ As we have seen, and as Bix notes, it is clear that Kelsen emphasizes that although one may, one does not have to, presuppose the basic norm, which is to say that although one may, one does not have to, conceive of law as a system of valid norms. On this analysis, then, the validity of law is conditional upon the presupposition of the basic norm, and the presupposition of the basic norm is in turn conditional upon the wish of the person making the presupposition to conceive of law as a system of valid (binding) norms. As Kelsen puts it, the basic norm only plays an epistemological - not a justificatory - role in the analysis (1992: 58 and 64; 1960: 224). Here is Kelsen in the second edition of the Reine Rechtslehre:

It [the Pure Theory] describes positive law, i.e. every on the whole effective coercive order, as an objectively valid normative order, and establishes that this interpretation is only possible under the condition that a basic norm is presupposed whereby the subjective meaning of the law-positing acts is also their objective meaning. It thus characterizes this interpretation as a possible one, not as a necessary one, and portrays the objective validity of positive law as conditioned only: as conditioned by the presupposition of the basic norm. That one only can, not must, presuppose the basic norm of a positive legal order means that one can, but not must, interpret the interhuman relations under consideration normatively, i.e. constituted through objectively valid norms as duties, authorizations, rights, competences, etc., that one can interpret them unconditionally, i.e. without presupposing the basic norm as power relationships, as relationships between persons commanding and persons obeying or not obeying, i.e. sociologically, not juristically. Since - as was stated above - the basic norm, as a norm conceived in the establishing of the validity of positive law, is only the transcendental-logical condition of this normative interpretation, it does not serve an ethical-political, but rather an epistemological function. (Kelsen 1960: 224-225. See also Kelsen: 1991: 255-256 and 206; Kelsen 1992: 34 and 58; and Kelsen 1999: 394-395). ${ }^{3}$

12 I just said that, on Kelsen's analysis, the validity of law is conditional upon the presupposition of the basic norm. But this may be inaccurate. Joseph Raz proposes a slightly different interpretation of the function of the basic norm in Kelsen's theory, namely, an interpretation in terms of the notion of a detached legal statement. Having introduced the concept of the legal man - the legal man accepts the law of the land as his personal morality - Raz (2009: 140-143) proposes instead, that on Kelsen's analysis, legal scholars and others adopt the point of view of the legal man, albeit in a detached, rather than committed way. The reason is that they want to be able to conceive of law as a system of valid (binding) norms for the purely intellectual purpose of discussing its correct interpretation and application. As Raz (2009: 142-143) puts it

[1]egal science is not committed to regarding the law as just. It adopts this point of view in a special sense of 'adopt'. It is professional and uncommitted adoption. Legal science presupposes the basic norm not as individuals do-i.e. by accepting it as just-but in this special professional and uncommitted sense.

This means that on Raz's analysis, Kelsen does not conceive of the normativity of law as being conditional upon the presupposition of the basic norm, but as being unconditional when seen from a certain point of view, namely, the view of a person who believes that law is morally binding, a point of view that one may or may not adopt as one sees fit. The difference between these two ways of conceiving legal normativity is thus the difference between (i) a conditionally normative, that is, descriptive, and (ii) a categorically normative, albeit detached, interpretation of legal statements. As interpreted by Raz, Kelsen's claim about the normativity of law is that the normativity is to be found not in 
law itself, but in the characteristic practice of various legal actors making normative but detached first-order claims of law, rather than conditional and descriptive second-order claims about law.

Bix also considers Hart's theory of law and proposes that it could be read as operating with a sui generis form of normativity (Bix 2018: 34). Although he does not say so, he could have adduced as an argument in support of this claim that, on Hart's analysis, the word 'obligation' has a specifically legal sense, which differs from the sense it has when it occurs in a moral context. As Hart (1982: 60) sees it, a first-order legal statement (a 'committed statement,' in Hart's terminology) that a person has a legal obligation to perform an action refers to an action that is "due from or owed by" the person having the obligation in the sense that it "may be properly demanded or extracted from him according to legal rules or principles regulating such demands for action." As I understand it, Hart is simply saying that if one has a legal obligation, one ought legally to perform the relevant action. The general view, that key normative terms have a specifically legal meaning, which differs from the meaning they have in a moral context, has been called the semantic thesis of legal positivism, though not all legal positivists accept it. ${ }^{4}$

15 For this reason (and perhaps others), Bix may be right that Hart thought of legal normativity as a sui generis form of normativity. Such a conception of normativity is not without its problems, however. First, as Bix notes, we have two types of reasons for action that we understand fairly well, namely, moral reasons and prudential reasons. Thus, to think of legal reasons as either moral or prudential reasons is to understand them in terms of either of two well understood types of reasons for action. If, however, we decline to carry out such a reduction and continue to operate with a sui generis category, namely, legal reasons, the question of how to relate these different types of reason for action to one another will immediately arise. If legal normativity and moral normativity are different types of normativity, how do legal rights and obligations enter into the general flow of practical reasoning? In any case, I cannot recall having read anything by Hart on this topic, and this suggests to me, albeit weakly, that he did not really think of legal normativity as a sui generis form of normativity. I also note that Bix does not make any effort to elucidate the notion of a sui generis legal normativity that he attributes to Hart or relate it to other types of normativity, such as moral normativity. It would have been interesting to get his views on the relation between these different types of normativity.

Second, as we have seen, Raz maintains that Hart operates with a conception of social normativity, a view that I myself find plausible. I would be inclined to argue that Hart's sui generis conception of normativity is to be understood along the lines of what Raz calls social normativity, though I have to admit that the latter conception of normativity appears to be perfectly general and applicable to many different fields where normativity occurs. If this avenue is closed, however, one will have to say something about which interpretation of Hart's theory of law is better. It would have also been very interesting to get Bix's view on these problems.

Finally, whether one attributes Hart the view that legal normativity is a form of social normativity or a sui generis type of normativity, it is worth noting that there appears to be general agreement among legal philosophers that something like justified normativity is, and should be, at the center of the debate about the normativity of law (see, e.g., the essays in Bertea \& Pavlakos 2011). That law is necessarily normative in the social sense is clear, at least on a legal positivist analysis, which emphasizes the social efficacy of law - 
but it is not very interesting. The question of whether law is necessarily normative in the sense of justified normativity, on the other hand, is of considerable interest. For this is the question of whether it is in the nature of law to obligate. What this means, then, is that Hart's account of the normativity of law does not appear to be aimed at the same problem as the accounts forwarded by many other legal philosophers. But if this is so, one may well wonder at what problem it is directed. Perhaps Hart would have said that he is simply trying to account for the use of normative language on the part of judges, legal scholars, and others. It would have been interesting to get Bix's thoughts on this.

Despite my objections, I find Bix's article well worth reading. In this article, as in other articles, Bix always throws light on the topic he is treating.

-Acknowledgment.-I would like to thank two anonymous reviewers for helpful comments on the text.

\section{BIBLIOGRAPHY}

Stefano BERTEA \& George PAVLAKOS (eds.), 2011: New Essays on the Normativity of Law. Oxford and Portland, Oregon: Hart Publishing.

Brian H. BIX, 2018: Kelsen, Hart and legal normativity. Revus. Journal for constitutional theory and philosophy of law (2018) 34. 25-42. URL: https://journals.openedition.org/revus/3984. DOI: $10.4000 /$ revus.3984.

David COPP, 2007: Morality in a Natural World. Cambridge: Cambridge University Press.

H. L. A. HART, 1982: Essays on Bentham. Oxford: Clarendon Press.

Richard JOYCE, 2001: The Myth of Morality. Cambridge: Cambridge University Press.

Hans KELSEN, 1960: Reine Rechtslehre [The Pure Theory of Law]. $2^{\text {nd }}$ ed. Vienna: Franz Deudicke.

Hans KELSEN, 1991: General Theory of Norms. Eds. Kurt Ringhofer and Robert Walter. Trans.

Michael Hartney. Oxford: Clarendon Press. (Originally Published 1979 under the title Allgemeine Theorie der Normen by Manz, Vienna.)

Hans KELSEN, 1992: Introduction to the Problems of Legal Theory. Trans. Bonnie Litschewski Paulson and Stanley L. Paulson. Oxford: Oxford University Press. (Originally published 1934 in German under the title Reine Rechtslehre. Einleitung in die rechtswissenschaftliche Problematik by Franz Deudicke, Vienna.)

Hans KELSEN, 1999: General Theory of Law and State. Trans. Anders Wedberg. Union, New Jersey: The Lawbook Exchange. (Originally published by Harvard University Press: Cambridge, Mass 1945.)

Neil MacCORMICK, 1987: Comments. In Ruth Gavison, ed., Issues in Contemporary Legal Philosophy: the Influence of H. L. A. Hart, 105-13. Oxford: Oxford University Press.

Joseph RAZ, 2009: Kelsen's Theory of the Basic Norm. In Joseph Raz, The Authority of Law, 122-145, Oxford University Press: Oxford. 
Torben SPAAK, 2018: Legal Positivism, Conventionalism, and the Normativity of Law.

Jurisprudence (2018) 9(2). 319-344. URL: https://www.tandfonline.com/doi/

abs/10.1080/20403313.2017.1411116. DOI: 10.1080/20403313.2017.1411116.

\section{NOTES}

1. I assume that Raz means that if a standard has been accepted by personal commitment, it applies and binds the agent by virtue of this personal commitment. For a clear, and in my view plausible, explication of the categorical quality of normativity, see Joyce 2001: ch. 2.

2. I draw here heavily on my discussion of the theory of the basic norm in Spaak 2018.

3. Translated into English by Robert Carroll. The German original reads as follows: „Sie [the Pure Theory] beschreibt das positive Recht, das heißt jede im großen und ganzen wirksame Zwangsordnung, als eine objektiv gültige normative Ordnung und stellt fest, daß diese Deutung nur unter der Bedingung möglich ist, daß eine Grundnorm vorausgesetzt wird, derzufolge der subjektive Sinn der rechtsetzenden Akte auch ihr objektiver Sinn ist. Sie kennzeichnet damit diese Deutung als eine mögliche, nicht als eine notwendige, und stellt die objektive Geltung des positiven Rechts nur als bedingt: durch die Voraussetzung der Grundnorm, bedingt, dar. Daß man die Grundnorm einer positiven Rechtsordnung nur voraussetzen kann, nicht voraussetzen muß, besagt, daß man die in Betracht kommenden zwischen-menschlichen Beziehungen normativ, das heißt als durch objektiv gültige Rechtsnormen konstituierte Pflichten, Ermächtigungen, Rechte, Kompetenzen usw. deuten kann, aber nicht so deuten muß; daß man sie voraussetzungslos, das heißt: ohne die Grundnorm voraussetzen, als Machtbeziehungen, als Beziehungen zwischen befehlenden und gehorchenden oder nicht gehorchenden Menschen, das heißt soziologisch, nicht juristisch deuten kann. Da - wie gesagt - die Grundnorm als eine in der Begründung der Geltung des positiven Rechts gedachte Norm nur die transzendenthal-logische Bedingung dieser normativen Deutung ist, leistet sie keine etisch-politische, sondern eine erkenntnistheoretische Funktion.“

4. MacCormick 1987 did not accept the semantic thesis, arguing as he did that legal and moral normative terms have the same meaning.

\section{ABSTRACTS}

Brian Bix discusses questions of legal normativity, arguing (1) that Hans Kelsen's theory of the basic norm is best understood as saying that a person may choose to presuppose the basic norm in order to interpret the actions of legal officials normatively; (2) that H. L. A. Hart is best understood as espousing a sui generis view of legal normativity; and (3) that Hart's view is preferable to the rather popular view that law makes some sort of moral claim. I accept (1) but think it is rather trivial. I find (2) plausible but the view itself problematic, and am therefore skeptical of (3). 
INDEX

Keywords: Kelsen (Hans), Hart (H.L.A), Raz (Joseph), justified normativity, social normativity, basic norm, legal positivism, Hume's law, detached statements

\section{AUTHOR}

\section{TORBEN SPAAK}

Professor of Jurisprudence, Department of Law, Stockholm University (Sweden).

Address: Stockholm University - Juridiska institutionen - 10691 Stockholm - Sweden

E-mail: torben.spaak [at] juridicum.su.se 